\title{
Percursos em campo: interseções entre conhecimentos e práticas.
}

\author{
Hélio R. S. Silva ${ }^{1}$
}

\section{Prá começo de conversa. 00}

O tema desta conversa é quase tudo que cerca, envolve e dá substância à prática etnográfica. Como se trata de uma fala em torno de uma prática, fica mais fácil falar a partir daquilo que nós próprios praticamos. Se fosse discutir teoria ou metodologia, optaria por trabalhos mais representativos da experiência etnográfica. Como vou discutir as intersecções entre teoria e prática, preciso de intimidade com o material.

Esta opção me mantém fiel ao tema deste seminário. Daí a apropriação na minha fala do próprio título do seminário.

Falarei sobre alguns trabalhos, alguns publicados, outros ainda inéditos.

Acentuarei essa dimensão prática da experiência, rente aos percursos, na divisão ansiosa, relutante e duvidosa impostas pelas clivagens entre conhecimentos e práticas. Busco esclarecer isso porque ando entusiasmado com a nova geração de cientistas sociais. São tributários de uma tradição com a qual não contei. Têm intimidade precoce com nossas questões e nosso jargão e parecem transitar com aisance em torno das questões clássicas e das novas questões das Ciências Sociais.

Suponho que a discussão que levou à escolha do tema do seminário se processou em termos diferentes daqueles que me agitavam nos meus tempos de estudante. Diria, sem temer o paradoxo, que foram definidos em

\footnotetext{
${ }^{1}$ Etnógrafo, Professor Visitante da FEBF/UERJ e Presidente do ISER.
} 
termos maduramente jovens. Tal maturidade é sinal de envolvimento com uma linguagem que amadureceu com o tempo e tornou-se fluente. Vocês são tributários dessa influência e seus praticantes, o que assegura passos novos. Para mim, as Ciências Sociais começam no Brasil.

Cultivem a mestranda insegurança como antídoto para a doutora segurança dos transeuntes de pedestais. Não há pior inimigo do cientista social do que os elogios dos parentes, amigos, alunos e colegas. O saudável exercício da autocrítica e da crítica produz a têmpera necessária ao enfrentamento dos complexos problemas das sociedades de hoje que parecem projetar perspectivas de radicais transformações constantes, ora sombrios, ora promissores. Em tais cenários, vocês transitarão, em constante embate entre os conhecimentos adquiridos e as revisões necessárias. A fluência referida há pouco é pré-requisito indispensável à flexibilidade dos exercícios de autoavaliação.

Falemos portanto de insegurança e dessa tensão entre a sociedade observada, o objeto em construção e os impasses do observador.

Eis o nosso tema: as inseguranças em campo, a insegurança como o sentimento ético para quem parte para o campo com uma questão, que é em última instância, uma dúvida, o que suscita insegurança. Esta a nossa fiel companheira no campo.

Estamos inseguros porque estamos ante uma questão prática. Há um senso comum que nos vê sempre como inteiramente teóricos. Chesterton dizia que louco é aquele que perde tudo menos a razão. O puro teórico seria um inquilino razoável de um Hospital Psiquiátrico, de antes do movimento antimanicomial. Assim como alguém exclusivamente prático não passaria de um animal adestrado. Esta é uma lição que aprendemos com a Antropologia Clássica. Em qualquer experiência humana essas duas 
dimensões estão presentes. Inclusive na experiência do sociólogo e do antropólogo.

A questão inicial em torno do trabalho etnográfico é a da leitura do contexto onde se busca resposta para a questão formulada no projeto de pesquisa. Os contatos iniciais dão a sensação de que tudo ali está desarrumado. E nenhuma experiência conjura tal sensação. Afinal, cada nova pesquisa encerra um problema novo. E só há sentido na pesquisa se for novo o problema.

Eis o desafio e o grande prazer intelectual da aventura. A desorientação, a desarrumação vão sendo substituídas aos poucos pela lenta "arrumação" dos percursos, pelo que se vê, pelo que se ouve, pelo que se testemunha, pelas informações das entrevistas, pelas releituras do diário de campo, pela consulta a todo material escrito ou já publicado sobre o passado daquela população, daquele grupo, daquela sociedade.

Há apenas uma diferença entre a insegurança do velho profissional e a do novato. É que, no último caso, a insegurança apenas se acentua porque sobreposta às tensões inerentes à obtenção de um título, de mestre ou doutor. De resto, está sempre presente no trabalho de campo, é inerente à observação participante, que tem como foco práticas sociais, o cotidiano e o envolvimento com pessoas desconhecidas com as quais devemos estabelecer alguma intimidade.

Dá-se aí o trânsito da leitura do texto (com suas implicações consensuais em torno da oposição ler X escrever, contido no ditado latino, "primeiro viver, depois filosofar") para essa outra leitura, a leitura da vida escorrendo nas ruas, onde uma questão qualquer pode ser provada e, com sorte e talento, as hipóteses comprovadas. A leitura enfim da própria realidade, matéria afinal dos livros lidos. Transcender a mediação do 
próprio texto (sem efetuar uma oposição pueril entre eles) é uma experiência fascinante.

Estamos em campo, guiados por formulações teóricas e observações metodológicas, mas entre umas e outras, como praticantes do exercício da observação, estamos nós como mediadores e a nossa vivência como mediação.

\section{Pesquisa.01}

Dito isso, eu queria passar para uma pesquisa concluída, mas cujo texto encontra-se em processo de revisão. Venho me dedicando a ele há muito tempo. Encomenda do Dr. Sérgio Góes que, na época, trabalhava na Presidência da Fiocruz, foi suscitada pela posse por parte da Fiocruz de parte do território da antiga Colônia Juliano Moreira. Desativada após um fértil processo antimanicomial interno e com a municipalização dos serviços de saúde.

Trata-se de área contígua ao Parque Estadual da Pedra Branca, mancha sobrevivente da Mata Atlântica, ${ }^{2}$ partilhada entre o Exército Brasileiro, a Prefeitura do Rio de Janeiro e a Fiocruz.

Esses terrenos herdados tinham sofrido, durante muito tempo, um contínuo processo de invasão. Eu chamo de invasão, e acho que há uma distinção entre invasão e ocupação. Acho que não é interessante para um cientista social aceitar esse discurso "politicamente correto" que nos obrigaria a chamar de ocupação e de ocupantes, porque os dois processos são absolutamente distintos. O que me interessa é dar sentido sociológico

\footnotetext{
${ }^{2}$ Sobre o tema, Dean, Warren. A ferro e fogo: a história e a devastação da Mata Atlântica brasileira; $O$ sertão carioca; coletânea do professor da PUC.
} 
às duas expressões. Há um processo social de invasão, que pressupõe disposições e um tipo de organização que não são as mesmas do processo de ocupação. Isso avulta claramente, sobretudo numa das áreas ocupadas, atualmente, e que foi invadida por um grupo em um lugar chamado Entre Rios. Por acaso, essa área, que é contígua à área da Fiocruz, não pertence à Fiocruz. Mas dadas as condições e a recepção que eles tiveram comigo, foi o lugar que escolhi para trabalhar.

Então, vejam bem, a Fiocruz herda esse espaço com esses ocupantes, esses moradores, que invadiram um terreno do Estado. Quer dizer, a questão toda da Fiocruz, era como estabelecer um campus com um número grande de moradores dentro e com a perspectiva, esta natural, de que a população cresça. Mulheres grávidas, crianças nascendo, filhos casando.

Enfim, como administrar um campus, como ter um campus, como organizar uma atividade científica em meio a moradores? Então você tem uma discussão imensa. Sérgio Góes, que me convidou para trabalhar, tinha a idéia de empregar a todos, de envolver todos como funcionários do novo campus. Alguns outros achavam que isto seria impossível. Então você tinha uma divisão interna na Fiocruz em torno dos destinos do campus, ou da forma como o campus seria apropriado. Discussões intermináveis sobre se cabe expulsar liminarmente essa população, indenizando-a ou conviver com ela. Assimilando a população como funcionários ou criando-se uma divisão extremamente complicada, porque a ocupação da Fiocruz estava dividida em "comunidades" - como gostam de dizer as assistentes sociais.

Meu trabalho consistia em tentar entender essa população e realizar dois seminários com a equipe da Fiocruz que iria construir e organizar o novo campus. 
São muitos os atuais ocupantes que, muito antes da invasão, tinham o hábito de visitar a Colônia em grupos de familiares, amigos e vizinhos. Os futuros invasores coincidentemente são formados por redes de vizinhos, amigos e familiares.

Na decisão de invadir, duas claras possibilidades: aqueles que não querem invadir - "meu cunhado não quis", "minha mãe não quis" - e outras que invadem - "para se livrar da tirania do aluguel".

Jacarepaguá era muito longe. Jacarepaguá mudou de lugar. Não está mais onde estava. Não havia a estrada Grajaú-Jacarépagua, não existiam os túneis. Na década de trinta, Armando de Magalhães Corrêa publica $O$ Sertão Carioca, um livro sobre a Barra da Tijuca, Recreio dos Bandeirantes e Jacarepaguá. Explora o paradoxo entre a proximidade geográfica e a distância de acesso. Esta última, a ele parecia, explicaria a considerável distância econômica, social e cultural do lugar em relação ao centro do Rio e a Copacabana. Um mundo rural e rústico contíguo à "cosmopolita" e "aristocrática" zona sul, então "Princesinha do Mar". É o momento em que se começa a criar o mito de Copacabana.

Essas duas circunstâncias cruzadas conferem ao discurso legitimador daqueles ocupantes uma propriedade que a equipe nunca conseguiu entender: a invasão de seus ancestrais estava legitimada por esse pioneirismo e integrava a própria formação do lugar. Eles eram o lugar. $\mathrm{O}$ lugar eram eles, era deles. Isso, é claro, colide com os dispositivos legais e com as prerrogativas da União.

O que fazia a Fiocruz? Uma intervenção social. As equipes com as quais eu trabalhava faziam uma intervenção social - as assistentes sociais uma intervenção ambiental - os engenheiros florestais - e outros especialistas. Programas de replantio, censo que levava os recenseadores a 
bater de casa em casa, reuniões para tomada de decisões que a todos atingiam, interdição de reformas em suas casas sem a prévia autorização da Fiocruz. Em meio a toda essa efervescência estão os nativos que querem tudo, precisam de tudo, menos de efervescência.

Os invasores, ocupantes, moradores, nativos, como queiram, constroem toda uma fabulação sobre as origens daquela região. E toda essa fabulação reforça a idéia de pertencimento de sua população. $\mathrm{O}$ curioso é que, ao contrário da população de Entre Rios que se situa em terras hoje da Prefeitura, o discurso das populações residentes na fatia da Fiocruz articula a presença deles à origem "aristocrática" do bairro de Jacarepaguá. Porque o bairro de Jacarepaguá na década de vinte, era um bairro "aristocrático". Getulio Vargas, já na década de trinta, o frequentava em almoços elegantes nos casarões da elite da época. Várias famílias "importantíssimas", no sentido tradicionalmente aristocratizante, ali residiam ou mantinham casas de veraneio. Havia, portanto, fazendas, sítios, grandes propriedades com vida social intensa.

Os ocupantes atuais falam muito do Barão de Taquara e de outros personagens "ilustres" que habitaram o lugar. Essa legitimação é feita a partir desse fundo aristocrático e do privilégio de morar em um lugar sem tráfico, sem os índices alarmantes de criminalidade, que se tornaram a mais notória instituição carioca. Cercada por seguranças, com as entradas controladas lembram o sonho do condomínio fechado da alta classe média carioca. Com uma vantagem. Enquanto estas contam com pingadas árvores de folders publicitários, os moradores da ex-Colônia têm a seus pés uma das mais interessantes sobrevivências da Mata Atlântica.

O contato com a natureza faz com se digam coisas como a que me disse um líder local: "eu tenho direito a qualidade de vida". É essa a idéia. 
Com exceção de Entre Rios. Mas os grupos que estão na área da Fiocruz têm esse tipo de fabulação.

Aí eu trabalho toda essa relação da Fiocruz com aquela população que está lá e focalizo mais Entre Rios, onde tive um melhor acesso e uma recepção mais positiva, pois não era identificado como um preposto da Fiocruz e nem isso seria um problema, pois se tratava de terras da Prefeitura.

A líder local fez uma reunião em sua casa. Convidou trinta moradores. Apresentou-me e disse que me confiava um trabalho de descrever a origem do "bairro" e que, para tal, precisava entrevistá-los.

Todas essas pessoas me concederam entrevistas, todas gravadas. Buscava restaurar a memória da invasão e da construção da ocupação.

Ficou claramente delimitado de onde vieram. Quase todos vêm de Jacarepaguá e quando provêm de outro lugar, são familiares ou amigos de algum invasor.

Trata-se, pois, de descrever a invasão a partir das versões de seus invasores, que não são homogêneas e são muitas vezes contraditórias e conflitantes; e a ocupação.

Toda a ocupação foi muito tensa. Idas e vindas que exigiram a formação de alianças com um Senador, deputados, vereadores, secretários de Estado. Eles conseguiram uma articulação notável.

O mais importante para entender o cotidiano da Colônia foram dois livros sobre Arthur Bispo do Rosário, um de Patrícia Burrowes, outro de Luciana Hidalgo ${ }^{3}$. Foram surpreendentemente de muito mais valia do que relatórios e textos de psiquiatras e funcionários ligados à administração.

\footnotetext{
${ }^{3}$ Hidalgo, Luciana. Arthur Bispo do Rosário, o senhor do labirinto. Rio: Editora Rocco, 1996 e Burrowes, Patrícia. $O$ universo segundo Arthur Bispo do Rosário. Rio: Editora FGV, 1999.
} 
Entrei realmente nesse hospício "pelas mãos" de Artur Bispo do Rosário. Trata-se de figura paradigmática. Tratam de sua arte e da personalidade ímpar do artista. A inscrição que as duas autoras e alguns outros trabalhos fazem de Arthur no contexto da Colônia esclarece de modo extraordinário aquela pequena sociedade. $\mathrm{O}$ alcance antropológico dessas biografias e estudos são notáveis. Rosário é fascinante porque no interior de uma instituição do controle, reverte o jogo e passa a controlar. Ele diz assim: "olha, me prendam". Ele dizia quando ele ia entrar em crise, ele dizia para os médicos quando devia tomar remédio, dizia quando deveria ser colocado na camisa de força.

Exímio trançador de fios, sua presença na Colônia é ela mesma um fio para penetrar na labiríntica instituição. A circunstância de ter sido um sujeito que usava (ou que usavam) sua força física ${ }^{4}$ para conter alguns surtos mais perigosos revela muito das práticas rotineiras da Colônia.

Esse é o trabalho sobre a Colônia Juliano Moreira, o trabalho da Fiocruz, que eu estou revendo, em diálogo permanente com Sergio Góes, que trabalhava na presidência da Fiocruz e que foi quem me chamou para fazer o trabalho.

Eu queria só ler um trechinho de um registro. No auge da crise, quando eles começam a negociar com o diretor da Colônia, teve guerras campais dentro da Colônia, eles puseram arame farpado em toda uma rua. Polícia Militar entrava. Esse Chico Preto é uma figura impressionante. Agora, a corrupção grassava solta, porque desde há muito tempo, tanto na Colônia Juliano Moreira quanto na Colônia de tuberculosos de Curicica, você tinha uma conivência de funcionários invasores. Um diretor administrativo da Colônia tinha uma tabela, ele vendia terreno - saiu no

\footnotetext{
${ }^{4} \mathrm{E}$ habilidade técnica, pois Bispo fora boxeador.
} 
Jornal do Brasil e tudo. E esse Chico Preto é uma figura muito curiosa, porque ele reprime, cede, reprime, cede - durante o movimento antimanicomial. Ai, nessa briga, tem uma hora muito tensa - mais de três pessoas me contaram essa história: uns moradores no gabinete do diretor da Colônia, que era um médico, discutindo e ele vira e diz assim "olha, façam o que vocês quiserem, mas façam tudo para eu não saber." Quer dizer, a luta toda ali se trava em torno desse direito à moradia. Uma insubordinação andrajosa, tosca, de uma fatia da sociedade que sabe que não pode esperar o bolo da economia da sociedade crescer para ganhar sua parte.

\section{Entre a teoria e o método.02}

02.01 Supressão das informações de cúpula (eu não era da Fiocruz, a questão da preservação institucional).

02.02 Quando se trabalha com uma situação "real", com o que se costuma chamar de "gente de carne e osso", com conflitos, desentendimentos, é praticamente certo encontrar-se com séries distintas intrinsecamente constituintes do "imbróglio" em pauta. Não há, portanto, paradoxo em que um especialista em leitura de interações face a face, refugie-se com certa freqüência na Guanabarina da Biblioteca Estadual ou no arquivo de algum colecionador maníaco. No caso, o meio ambiente, o cenário desses (des)encontros.

02.03 Ter coragem de enfrentar o que se convencionou chamar entre nós de politicamente correto.

Há uma diferença entre ocupantes e invasores. Eu acho que o processo de invasão, que detalho: uma líder muito interessante - ela me deu acesso porque ela liderava a invasão. E ela me disse "ocupação não, 
invasão. Eu sou uma invasora assumida". Ela então não somente articulou toda a invasão, toda a estratégia (a estratégia é interessantíssima: eles tinham que atravessar um rio de noite e tinham que construir uma casa antes que amanhecesse). Esse processo todo, as articulações, o sistema de produção é uma coisa muito rica - é a base da etnografia. Eu não posso, evidentemente, explicitar aqui, mas eu acho que as estratégias usadas, as disposições acionadas, as articulações, o tipo de socialização, de interação da invasão é uma e da ocupação é outra. Porque uma vez ocupado você tem que organizar aquela sociedade.

Algumas pessoas parecem dotadas de uma disposição guerreira, coragem para enfrentar o inusitado, mas desprovidas de qualquer paciência para o trato das tarefas cotidianas e reiteradas de ordenação da vida social. Estabelecer o tamanho da rua, qual sua largura. As comezinhas regras de convivência parecem se atritar com certos atores atraídos pela aventura da invasão, a exigir ímpetos transgressores, ousadia e certo voluntarismo.

A líder da invasão de Entre Rios talvez devesse sua ascendência sobre a comunidade exatamente por ter sido capaz ao longo de todo o processo de combinar as duas disposições, em princípio antípodas. Essa senhora começa a controlar os ímpetos e os voluntarismos. Até os limites de uma burocratização ${ }^{5}$ consciente e extremamente eficiente. Uma moradora me disse: "passei dois anos para conseguir minha casa". Vinha quase semanalmente falar com a líder que lhe fazia perguntas, a tratava formalmente e pedia que retornasse em tal data. Havia uma ficha preenchida com os dados da postulante e anotações sobre a entrevista. Em sua entrevista, a líder me confessou que este era o recurso que tinha para

\footnotetext{
${ }^{5}$ Retiro da expressão toda sua carga negativa e a utilizo em seu sentido original,
} 
saber se o postulante era realmente carente: os verdadeiramente necessitados retornavam sempre.

02.04 Em um seminário onde expunha as idéias de Erving Goffman em "Framing Analysis", a questão da incomunicabilidade e da entropia produzida pelas comunicações e interações mais íntimas, resumi as idéias no dístico invertido "é conversando que a gente se desentende" para ouvir de um dos maiores especialistas brasileiros em Ecologia da Fiocruz que aquilo parecia conversa de Chacrinha.

02.05 Variáveis a serem enfrentadas (multiplicidade de variáveis a serem enfrentadas). Não se trata de uma particularidade da Etnografia, mas sim de uma propriedade do trabalho para o qual o futuro etnógrafo deve estar atento.

O meio ambiente, a natureza, cenário desses (des) encontros, torna-se a primeira variável significativa. Fonte de interesse científico, ecológico, preservacionista, mas fonte também de subsistência, que vai dos pequenos roçados à caça. Conflito gerado por diferentes concepções de natureza. ${ }^{6}$

Quando a Fiocruz estabelece limites à ocupação, às relações entre esses grupos e a floresta, um líder local afirmou numa reunião: “a Fiocruz gosta mais de planta do que de gente". Sentiam-se tolhidos e desrespeitados em sua vivência íntima com a natureza pelos almofadinhas da zona sul.

Outra variável importante era a própria formação do bairro de Jacarepaguá. Os invasores da Colônia vinham, sobretudo, de Jacarepaguá. Essas invasões eram precedidas pelo conhecimento da Colônia. Seus

\footnotetext{
${ }^{6}$ A Ecologia é o mais sofisticado campo de atuação dos charlatões. O que não significa dizer que todo ecólogo seja um charlatão.
} 
futuros invasores tinham hábito de passear pela Colônia, conheciam a vida dos internos, relacionavam-se com os internos.

Há uma terceira variável: a história da Colônia. Quando de sua inauguração, em 1923, seu diretor declarou perante o Ministro do Interior, que a Colônia teria como função recuperar o louco pelo trabalho e pelo contato com a natureza. Disse mais: é recurso civilizatório e que vai servir de anteparo para o perigo vermelho e o perigo anarquista. A Colônia chegou a abrigar sete mil internos.

Suprimir, tirar da sociedade, deixar em contato com a natureza e fazer com que eles trabalhassem. Em oficinas, faziam colchões e outros objetos.

Os médicos não iam lá todos os dias, alguns funcionários não iam lá todos os dias. Não porque fossem relapsos, mas porque esse trânsito diário era, em época remota, contraditória com a idéia de cotidiano, que é, sobretudo, a exploração das cercanias.

Responsabilidades e atribuições foram sendo aos poucos deslocadas para os funcionários menos especializados, aqueles que não faltavam e moravam em casas funcionais na própria instituição. Nesse regime, alguns "loucos" privilegiados, que assumiam a responsabilidade de aquietar o outro. Qual é a proeminência de Arthur Bispo do Rosário? Por que Arthur Bispo do Rosário tinha aquelas prerrogativas? Como se pode explicar que em uma Colônia onde as pessoas tinham catre, camisa, calça e sacola de brim onde depositavam todos seus pertences que era tudo que pudessem carregar no ombro.

Como se pode conceber que um homem que tinha como projeto reconstruir o mundo, e refazendo todos seus objetos, como adquire espaço para guardar todo esse acervo. Por quê? Porque Arthur Bispo do Rosário 
era, foi, campeão de boxe sul americano. Era uma pessoa importantíssima na Colônia porque ele era quem aquietava os doentes. Num lugar onde havia, por exemplo, um doente apelidado de Arranca Olho, cuja mania era enfiar os dedos na órbita ocular do interlocutor para arrancá-la.

Há ainda uma quarta variável, o movimento antimanicomial. Tradicionalmente, esses internos eram constituídos da nossa tradicional população de rua. Bêbados, desclassificados, negros, pessoas sujas, molambentos, arruaceiros revoltados - era essa a matéria prima dessas internações na sua grande maioria. Isso era conhecido pelos médicos quando começa o movimento antimanicomial. Basaglia vem ao Brasil mais ou menos no período de redemocratização. Há relatórios que dizem o seguinte: $60 \%$ das pessoas que estão aqui tem problemas decorrentes da internação. Há, é claro, pessoas com problemas - lesões cerebrais, enfim. Inclusive quando houve o processo antimanicomial e os internos foram recambiados para as suas famílias, algumas famílias não quiseram. Houve muitos funcionários que ficaram em suas casas com ex-internos. Quer dizer, quando houve .... houve um grupo que não podia sair. Então, quando eu cheguei lá, havia uns duzentos e poucos internos que ainda estavam lá. Inclusive o Maromba, que era uma pessoa interessantíssima, que tinha 102 anos - morreu com 104 anos - que era um extraordinário conhecedor de plantas. E vivia internado na floresta catando plantas, plantando e que tinha uma interlocução com os botânicos da nossa equipe muito freqüente. Havia também outro que era insuportável, um outro interno que toda a vez que me via - ele só fazia isso - ele te pedia um real. Se você não desse ele caia em cima de você feito um louco possesso (feito um louco, risos, desculpe). Ele ficava possesso, avançava, ficava agressivo. Se você desse, ele dizia "mas não é esse o um real". Então, ele estava permanentemente pedindo um real: 
se você não desse era agredido; se desse, não era aquele que ele queria. Havia um outro que conversava o dia inteiro com uma pedra que havia em frente ao pavilhão agrícola. Quer dizer, doença mental existe. Agora, é preciso distinguir e ver bem. No caso da Colônia você tem claramente um esquema fundamental de repressão. Basta dizer que em determinado momento, com essa ausência médica, com essa ausência de funcionários etc, os internos chegavam trazidos pela polícia. O diagnóstico era feito pelo policial. Em muitos casos é feita a referencia "ai o camburão chegou, deixou ele, o interno o arruaceiro, o sujeito que gritou, o sujeito que desacatou alguém”. Tudo isso virava louco. O desordeiro, o cachaceiro, o sem família. ${ }^{7}$

Com o processo antimanicomial, a instituição entra em crise. $\mathrm{O}$ processo antimanicomial no Brasil é curioso. As matrizes do movimento antimanicomial vêm da Europa; vêm de países com tradição democrática: vêm da Itália, vêm da França, vêm da Inglaterra. Basaglia, Laing, Cooper enfim, os autores que vocês conhecem - começam a fazer seminários constantes. A instituição começa a se reverificar, a se discutir, a se questionar. Está em crise, duvida de seus princípios e de suas finalidades.

É um processo riquíssimo fartamente documentado.

Curiosamente, apesar dessas matrizes de origem de países democráticos, se associa ao movimento de redemocratização. A discussão interna na CJM é de um processo antimanicomial que correspondia ao movimento da sociedade para se livrar da Ditadura. É como se o hospício, como se a Colônia fosse uma instituição da Ditadura. O que não é de todo absurdo. Não é absurdo de forma nenhuma, porque a República Velha, toda

\footnotetext{
${ }^{7}$ Não foi possível responder a uma questão que os textos da época nos coloca. Há evidentemente nesses casos uma discriminação entre casos de polícia e casos psiquiátricos.
} 
a Republica Velha é um período absolutamente ditatorial. Você tem Artur Bernardes que governa quatro anos em estado de sítio. Washington Luís que dizia que a questão social era um caso de polícia. A colônia é a quintaessência de uma sociedade autoritária.

Nesse momento, em que a instituição está em crise, ocorre uma frente imensa de invasões. Então, o movimento antimanicomial é extremamente solidário, está vinculado, está relacionado, forma o contexto do aumento de invasões. Não que não houvesse invasão sempre. Volta e meia, por exemplo - como é muito grande -, eu ouvi um senhor falar assim: "eu estava aqui há dez anos quando eles me descobriram". Você descobre uma casa que foi feita há dez, quinze anos. De repente está lá. O território não era completamente dominado. Você tinha dois seguranças. Tem um famoso, o Chico Preto. O Chico Preto era conhecido, todo mundo fala dele. Nesse período de intensa pressão sobre a CJM, que corresponde ao processo antimanicomial, corresponde a esse período de crise.

As invasões a conta gota eram comuns e tradicionais, não só na Colônia quanto no seu vizinho Sanatório para tuberculosos em Curicica. Mas, quando o processo intenso de discussão se instala e se instaura, há uma crise qualquer entre funcionários e administração que fragila vigilância ou as torna extrema e curiosamente ambígua. Temos então invasões em larga escala. Daí porque o movimento antimanicomial se torna uma variável fundamental para situar o fenômeno em foco.

02.06 Negociar presença - A equipe era formada por quatro assistentes sociais, o administrador, um botânico, dois engenheiros florestais e por mim, o etnógrafo. Grupo heterogêneo com o qual negociava cotidianamente minha presença ali. O que eu estava fazendo? Eu estava vendo tudo o que eles estavam vendo. E o que eu vou fazer com aquilo? 


\section{Pesquisa.03}

Esse trabalho foi encomendado pelo Governo do Estado do Rio, mais precisamente pelo CIDE (Centro de Informação e Dados do Estado), uma espécie de IBGE estadual, patrocinado pela UNESCO dentro do projeto Nova Baixada. Criado pelo Governador Marcelo Alencar, um Programa para a Baixada Fluminense chamado Baixada Viva, que depois se transformou, com Anthony Garotinho em Nova Baixada. Então o projeto Nova Baixada, Baixada Viva era um programa que abrigava um conjunto de projetos para a Baixada Fluminense. Projetos os mais diversos. Uma espécie de programa integrado. Então eu escrevi esse texto. Esse trabalho eu fiz, comecei em 2001, eu fiquei 10 meses. O trabalho é o seguinte: querendo saber o que é a Baixada Fluminense. Não tem literatura, muito pouco. Tem muita literatura lá. Tem muito livro na Baixada Fluminense, muito sociólogo, muito historiador, muito poeta, muito romancista, muito cronista, muito memorialista que fornece muito subsidio para um antropólogo. Tinha um diretor lá do CIDE que vivia dizendo para eu trazer a alma do Homem da Baixada, ai parecia uma coisa de centro espírita. Mas vocês conhecem esse tipo de jargão, um pouco meio folclórico, aquela coisa da essência do homem... "o que você quer que eu faça?" "Traga o homem, a alma do homem da Baixada". Ai eu disse: "vamos deixar por menos, eu faço o seguinte: vamos trabalhar a questão da integração da Baixada à metrópole". E eu sugeri que nós fizéssemos o seguinte, que nós tentássemos fazer a articulação da Baixada Fluminense com a metrópole em três planos: no plano simbólico pegando a Baixada, simbolicamente, como a antípoda da Zona Sul. E é assim que ela é pensada mesmo, a Zona 
Sul é exatamente seu oposto, e há um discurso sobre isso. Na Baixada muitas pessoas dizem, artistas etc, que a Bossa Nova é coisa de quem não faz sexo - "Quem faz sexo não faz aquelas letras". Então você tem alguns valores que se chocam mesmo, que estão em tensão. Ai eu pensei o seguinte: vamos pensar nas representações que fazem moradores da Zona Sul (Ipanema Copacabana e Leblon), empregadores de mão de obra da Baixada, que imagem eles fazem de seus empregados e da região de onde eles vêm. E vamos ver como é a partir de uma amostragem da Baixada Fluminense de representações sobre a Zona Sul: o que é a Zona Sul?; o que um pensa do outro?. Acontece que a Baixada é maior do que o Uruguai. Se você for pegar a população da Baixada, se você pegar, por exemplo, os maiores países do mundo, a Baixada está, como população, entre os maiores quarenta países do mundo. A Baixada tem quatro milhões de habitantes, então, quer dizer, como se faz uma etnografia da Baixada? Mas a Baixada nos interessa enquanto coisa mental. O problema dela não é concreto, geográfico. Não existe a experiência da Baixada em geral. Eu me lembro do Melo, um aluno perguntou uma vez para ele “... mas vocês antropólogos só falam sobre um grupo tribal, sobre uma esquina não sei onde, sobre o ritual da Penha, vocês não têm um discurso sobre a sociedade em geral?". E ele respondeu brilhantemente: "mas onde a gente pega o ônibus para ir até a sociedade em geral?".

Não há a experiência da sociedade em geral. Não há experiência da Baixada em geral. O que fiz? Integrei-me a uma rede. Fiquei primeiro - uns dez meses - em um lugar infecto, que é o Palácio Guanabara, com o pessoal que formula políticas para a Baixada Fluminense (um dos lugares mais terríveis que eu já vi na minha vida - nefasto). Depois disso, fiquei um tempo com a equipe que iria trabalhar na Baixada em frente ao Cemitério 
São João Batista. A equipe que trabalhava na Baixada Fluminense, que ia implantar o projeto, ficava em frente ao Cemitério São João Batista, há quarenta e cinco quilômetros da Baixada. Ou cinquenta. Do centro de Nova Iguaçu até o centro do Rio são 32 quilômetros - então uns quarenta, cinquenta quilômetros da Baixada. A coordenadora do grupo, uma historiadora da PUC, aceitou o cargo com uma condição: não ir à Baixada - "eu coordeno o trabalho desde que eu não vá à Baixada". Então, a evitação em relação à Baixada é muito forte. Mão Branca, Tenório Cavalcante, Zito - trata-se de qualquer jeito - dengue, peste. Depois disso, eu fiquei um ano morando na Baixada. Aluguei uma casa na Baixada e fiquei um ano morando lá. A pessoa que me alugou a casa é um compositor da Baixada - compositor, cantor, artista - foi Secretário de Cultura do Lindberg, é meu nativo, meu informante privilegiado. Informante privilegiado, para o antropólogo, é co-autor desprivilegiado. Nesse trabalho eu vou fazer o trabalho a quatro mãos. O trabalho será meu e do Roberto Lara, é uma etnografia minha e dele. Ele só tematiza a Baixada. A música dele é só sobre a Baixada, extraordinário. E há outros, como Roque da Paraíba, da primeira geração dos nordestinos que vieram para a Baixada, que tem uma musica que é um verdadeiro hino da Baixada Fluminense chamada "A carta vai, a carta vem”, que é uma música extraordinária. Então eu fiquei morando lá. Constituí uma rede de amigos; não peguei gravador e nem fui fazer entrevista formal. Comecei a freqüentar lugares onde eles estavam. Eu tinha o tempo todo. Fiquei um ano lá. Tinha um bar, o Bar Raízes. O Bar Raízes, em frente à Prefeitura de Nova Iguaçu, foi durante muito tempo o lugar para onde afluíam artistas plásticos - tinham mostras de artes plásticas uma vez por mês - compositores, cantores, escritores, poetas. Tinha um sujeito que passava um filme de arte todas as 
semanas. Ele tinha, em VHS, todo o neo-realismo italiano, todo o expressionismo alemão, todo o Godard, todo o Truffaut, ele tinha o cinema mundial. Ele passava os filmes e depois tinham os debates. Tinha um café literário, o Café Filosófico - eles usavam muito essa expressão. Evidentemente que eles discutiam muito a Baixada, o tempo todo. No meio disso, eu estava lá em minha casa e encontrei uma antropóloga francesa perdida. Me trouxeram "oh, essa moça veio da França, ela veio de Paris". Ela era orientanda do Isaac Joseph e veio para fazer um trabalho na Baixada. Aí eu a acolhi lá na minha casa, ela ficou morando lá também. E nós morávamos eu, ela e a Presidente do CIDE (na mudança de Governos do Garotinho para a Benedita) resolveu dar o exemplo e foi morar também na Baixada. Ai fiquei morando lá na Baixada com a Inês Patrício, uma economista, muito interessante, gozada, muito encantada, apaixonada pela Baixada. Uma aristocrata, descendente de Tomé de Souza, mas extremamente generosa e muito legal. Ela tinha uma visão das possibilidades econômicas da Baixada muito interessantes. E com a Jussara, que vocês devem conhecer, hoje trabalha na UFF lá em Campos, ficou no Brasil, casou. Então eu via: eu não posso ver a Baixada como um todo, mas posso ver essa rede. Não é a minha perspectiva particular da Baixada. Eu vou trabalhar com uma rede, a minha rede de vizinhos, essa rede de intelectuais, compositores, discutindo permanentemente a Baixada, discutindo permanentemente o Rio de Janeiro, discutindo a Metrópole. Então é uma possibilidade. Não há a possibilidade verdadeira. Você pega outro grupo em Caxias, pode ter algumas características diferentes; se você for a Queimados, outras. Comecei a fazer o trabalho em três planos: o plano das representações recíprocas - fazendo entrevistas com empregadores e habitantes de Ipanema, Copacabana e Leblon, vendo os 
transportes (o plano físico) como é que as pessoas se deslocam do trabalho para casa, trabalhando com pessoas idosas (um senhor extremamente lúcido, com 80 e tantos anos; uma senhora) gente com 70, 80 anos que mora na Baixada o tempo todo, como é que era o transporte antes, quanto tempo eles gastavam nesse transporte; como é que é esse deslocamento? Então eu comecei a fazer, a partir desses registros, uma etnografia do trem. Às vezes eu saia cinco da manhã para poder pegar o trem lá em Seropédica, Magé, enfim. E descia em vários horários do dia: na hora do rush, voltava na hora do rush. Comecei a fazer uma etnografia do trem e do metrô da linha 2. Quer dizer, comecei a fazer uma etnografia do trem e pegar os relatos do trem e de sua história. E comecei a estudar a historia das ferrovias do Rio de Janeiro. Das oitenta e poucas, acho que são oitenta ou noventa estações de trem, eu sei a história de todas elas. Eu sei a historia de todas as estações que existem e que existiram e já desapareceram. Sei porque deram os nomes, comecei a descobrir isso. Faltam duas ou três que eu não sei ainda, mas irei descobrir. As ferrovias não foram feitas para a população da Baixada. Houve lutas, movimentos sociais na Baixada para que o trem fosse para lá. Os trens foram feitos para ver o reservatório de água, trazer víveres para o Rio de Janeiro - os trens atravessavam a Baixada com outras finalidades. Houve lutas intensas para que a população da Baixada tivesse o direito a usar o trem. A primeira linha - inaugurada por Irineu Evangelista de Souza ligava o verão ao inverno. Era uma linha para a corte veranear em Petrópolis. Havia o passeio de barco pela Baia, sofisticado, com licores. O Carl Von Koseritz, aquele viajante, descreve isso. Ele chama Petrópolis de "a cidade entre nuvens" e descreve o caráter aristocrático desses passeios. Parece aqueles passeios de barco da aristocracia inglesa para o qual Handel descreveu a Suíte Aquática. É um 
pouco esse o clima. Ligava o verão ao inverno. No verão você vai para Petrópolis, porque ninguém é de ferro.

Comecei a trabalhar, portanto, nesse plano das representações, no plano das linhas férreas e no plano das políticas públicas. Para resumir, o plano do trabalho é o seguinte: eu abro com uma introdução, onde faço um histórico da Baixada Fluminense (a Baixada Fluminense sempre esteve integrada na história do Brasil, ela é uma área importantíssima desde o inicio do século XVI), então eu faço uma introdução chamada Gente reúna. Não sei se vocês conhecem um samba cantado pelo almirante "na Pavuna, na Pavuna, tem um samba que só dá gente reúna". Gente reúna é uma expressão da década de 20, 30 que significa gente bamba, gente legal, gente boa. Então eu começo a trabalhar com essa História da Baixada, região sudeste, Estado do Rio de Janeiro, Baia de Guanabara, via Dutra (a questão da via Dutra é importantíssima para a Baixada), municípios da Baixada aqui eu dou dados estatísticos sobre os municípios, os mapas dos municípios. Capítulo 1, portanto, a carta vai, a carta vem, sobre a integração da Baixada. Capítulo 2, Tomando de assalto, é um capítulo sobre as políticas públicas para a Baixada e os diagnósticos sobre a Baixada, que culmina com um trabalho que eu apresentei na ANPOCS no ano passado, que é a analise de um documento chamado marco zero. É um documento usado pela PNUD, pela UNESCO, OEA, pelo Banco Mundial, para trabalhos em áreas periféricas. É uma coisa enlouquecida. Esse trabalho eu apresentei e está nos anais da ANPOCS do ano passado. É o fundamento teórico da política feita para a Baixada. Ai eu falo sobre população, técnicos e políticos, entre a Baixada Viva e a Nova Baixada essa transição. O CID no contexto da administração estadual. Planejamento e controle, combate de políticas, escola de governo, barracão de obras. Eu 
escrevo no meio, depois desses dois capítulos, um intermezzo, chamado La serva padrona. Quer dizer, essa criada patroa é a antropologia. La serva Padrona é uma peça sinfônica, operística, uma pequena ópera que foi criada para os intervalos de uma ópera maior; enquanto a cena prossegue, mudança de cenário, você diverte a platéia com isso. Então no meio, aqui, eu botei isso que é um pequeno discurso sobre a antropologia no que ela interessa no caso da Baixada. Capítulo 3, Nos trilhos de Wanderley. Havia um trem que eles chamavam de Marta Rocha, depois apareceu um trem que eles diziam que era mais fresco, então chamaram de Wanderley Cardoso. Então, Nos trilhos de Wanderley, que divide o ramal de Saracuruna e o ramal de Belford Roxo. Ai eu começo a fazer uma etnografia do trem. E o capítulo 4, Linha Vermelha, é esse trabalho sobre as representações recíprocas que se divide entre ramal de Japeri, ramal de Santa Cruz, ramal de Deodoro, rodovias e terminais. Conclusão, chamada Improvável Manhã. Que é uma música do Roberto Lara.

\section{Pesquisa.04}

"Travestis - Entre o espelho e a rua", publicado pela Editora Rocco, nasceu de uma encomenda e cresceu como dissertação de mestrado graças à orientação do Dr. Rubem César Fernandes. Trabalho publicado não merece exposição detalhada. Foi encomendado pelo Ministério da Saúde, mais precisamente pelo Dr. Alvaro Matida. Na fase de encomenda meu principal interlocutor foi o Dr. Luiz Eduardo Soares, daqui da UERJ. E o "Travestis", era um livro encomendado para saber quem eram, como 
viviam e o que pensavam esses atores sociais. $\mathrm{Na}$ época não havia literatura sobre travestis.

\section{Pesquisa.05}

O fundamental em Vozes do Meio Fio é que não existia aquilo, "não tinha menino de rua no Rio", quer dizer, "não existe isso" - é o livro sobre o delírio de uma cidade. E neste sentido é que entendo sua importância se é que cabe a um autor dar importância a seu próprio trabalho. 